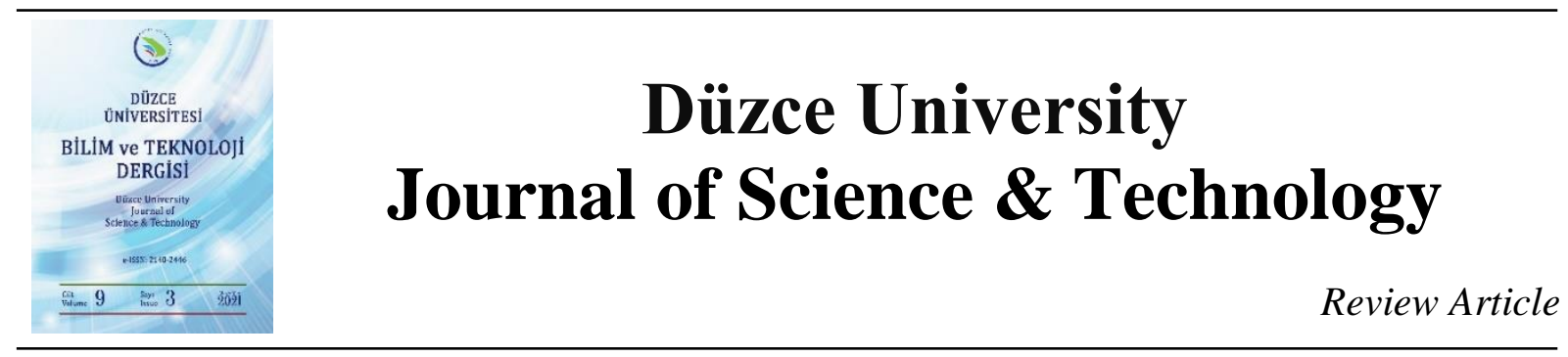

\title{
Analysis of Energy Supply, Installed Power and Renewable Capacity in the World, the EU and Turkey
}

\author{
Ali Naci ÇELİK ${ }^{\text {a,* }}$ \\ ${ }^{a}$ Department of Mechanical Engineering, Faculty of Engineering, Bolu Abant Izzet Baysal University, Bolu, \\ TURKEY \\ * Corresponding author's e-mail address: celikan@ibu.edu.tr \\ DOI: 10.29130/dubited.827250
}

\begin{abstract}
In the present study, a review of energy structure of the world, the European Union and Turkey are carried out, by giving a specific emphasis to the development of renewable energy. The global primary energy use reached 13865 Mtoe as of 2018. Today, more than $80 \%$ of the energy currently used in the world is still provided from fossil based non-renewable energy resources, the main energy resources being oil, coal and natural gas, with the shares $32 \%, 27 \%$ and $22 \%$, respectively. In the years after 1973 oil crisis, renewable energy emerged as a potential source for contributing to the global energy production. The installed capacity of renewable energy (excluding hydro) reached $1180 \mathrm{GW}$ globally as of 2018 that corresponds to an increase of $8 \%$ compared to the previous year. Amongst the renewable resources, wind holds the largest share with $563.7 \mathrm{GW}$, corresponding to $47.8 \%$ of the installed renewable capacity. Wind is closely followed by solar PV with $480.4 \mathrm{GW}$, constituting $40.7 \%$ of the total installed power of renewable energy. The total installed capacity of bioenergy (biomass, biofuels, and biogas) is 103.1 GW, corresponding to $8.7 \%$. The global capacity of hydroelectric power was realized as $1127 \mathrm{GW}$ as of 2018. Total of 1668.1 TWh electricity was generated in the world in 2018 by the renewable resources including wind, solar, geothermal, tide, wave and ocean.
\end{abstract}

Keywords: Global Energy Supply, Installed power capacity, Renewable capacity, Wind Energy, Solar energy, World, European Union, Turkey

\section{Dünya, Avrupa Birliği ve Türkiye’nin Enerji Arz, Kurulu Güç ve Yenilenebilir Kapasitelerinin Analizi \\ ÖZET}

Bu çalışmada, yenilenebilir enerjiye özel bir önem verilmek kaydıyla dünya, Avrupa Birliği ve Türkiye’nin enerji yapısının bir değerlendirilmesi yapılmaktadır. Küresel birincil enerji arzı 2018 yılı itibariyle 13865 Mtoe'ye ulaşmıştır. Bugün dünyada kullanılan enerjinin \%80'den fazlası halen fosil bazlı yenilenemeyen enerji kaynaklarından sağlanmakta olup, temel enerji kaynakları sırasıyla \%32 petrol, \%27 kömür ve \%22 doğalgaz olarak gerçekleşmektedir. Yenilenebilir enerji, 1973 petrol krizini izleyen yıllarda küresel enerji üretimine katk1 sağlama potansiyeli olan bir kaynak türü olarak görülmeye başlanmıştır. Hidrolik enerji hariç, kurulu yenilenebilir enerji gücü bir önceki yıla göre \%8'lik bir artış ile 2018 yılı itibarıyla dünyada 1180 GW'a ulaşmıştır. Yenilenebilir kaynaklar arasında rüzgar, toplam kurulu yenilenebilir kapasitenin \% 47.8'ine karşılık gelen 563.7 GW ile en büyük paya sahiptir. $480.4 \mathrm{GW}$ kurulu güç ile rüzgarı takip eden $\mathrm{PV}$, dünya çapında kurulu yenilenebilir enerji gücünün \% 40.7'sini oluşturmaktadır. Toplam kurulu biyoenerji kapasitesi (biyokütle, biyoyakıtlar ve biyogaz) 103.1 GW ile toplamda \%8.7'lik bir oranı teşkil etmektedir. Küresel hidroelektrik kurulu gücü 2018 yılı itibarıyla 1127 GW'a ulaşmıştır. Dünyada 2018 yılında, rüzgar, güneş, jeotermal, gelgit, dalga ve okyanus gibi yenilenebilir kaynaklarla toplam 1668.1 TWh elektrik üretimi gerçekleşmiştir.

Anahtar Kelimeler: Global enerji arzl, Kurulu güç kapasitesi, Yenilenebilir kapasite, Rüzgar enerjisi, Güneş enerjisi, Dünya, Avrupa Birliği, Türkiye 


\section{INTRODUCTION}

Energy need of humanity both as a whole and also as individual countries continues to increase regularly and as a result global primary energy supply and consumption increase steadily. In order to meet the continuously increasing global energy demand, the infrastructure to convert various forms of energy has to be increased proportionately, including the electricity generating capacity.

Historically, the global primary energy use was 486 Mtoe in 1800, of which 478 Mtoe was biomass and the rest was coal [1]. As of 1900, the global primary energy supply increased to 1100 Mtoe, biomass and coal contributing almost equally to the total amount. Fossil fuels being the major contributors, the present primary energy use has increased nearly 30 times since the 1800 s. The global primary energy use reached 13865 Mtoe as of 2018, particularly accelerating in 1950s [2]. Despite bioenergy falling to around $10 \%$ of global primary energy today, however, its annual consumption grew from 478 Mtoe in 1800 s to around 1194 Mtoe today.

Until 1950s, biomass and coal were the predominant energy resources. The electricity was also predominantly produced by biomass and coal historically. As well as the biomass and coal, starting from the 1950s, oil, natural gas and hydropower started to make a significant contribution for meeting the global energy demand and their use has been increasing steadily. With the advance of nuclear energy engineering, developed countries started building nuclear power stations in 1970s.

In the years following the 1973 oil crisis, which was caused by a series of political and economic reasons of the period, the efforts made to find new energy sources/conversion technologies as alternative to the fossil fuels increased rapidly and renewable energy emerged as a potential source for contributing to the global energy production. In the years following, as a result of the developments in renewable energy conversion technologies, the share of renewable energy started to increase steadily over the years in the world. On the other hand, the reason for this increase can be regarded as the countries' re-evaluation of their energy policies in line with the advance of renewable energy technologies and also due to various other reasons such as the rising energy demand, fuel prices and environmental concerns.

The orientation towards renewable energy was further encouraged by the environmental problems due to global warming. Rise in the global fossil fuel consumption has led to the phenomenon of global warming that has in turn upset the ecological balance of the earth [2]. Global warming and the related environmental problems have rendered it impossible to evaluate the fossil fuel consumption as just an energy-related problem. Therefore, the focus of search for new energy sources to replace fossil fuels was concentrated on renewable energy sources primarily, solar, wind, geothermal, bioenergy and wave energies and hydrogen as an energy vector. As a result of intense investments and the resulting research programs and projects, especially in developed countries, the technologies of such renewable energy systems experienced a rapid development in the past decades. The importance of renewable energy systems is expected to continue in the medium and long terms [3].

Today, however, more than $80 \%$ of the energy currently used in the world is still provided from fossil based non-renewable energy sources. The main energy sources are oil, coal and natural gas with the shares $32 \%, 27 \%$ and $22 \%$, respectively [4]. The global primary energy consumption grew at a rate of $2.9 \%$ in 2018 , while the supply of renewable energy grew by 71 Mtoe in the same year, corresponding to $14.5 \%$ increase compared to the previous year. Wind energy generation increased from $1128 \mathrm{TWh}$ to $1270 \mathrm{TWh}$, growing by $12.6 \%$ in 2018 , providing approximately $45 \%$ of the renewables growth in that year. Solar energy generation grew by $29 \%$, increasing from $453.5 \mathrm{TWh}$ to $584.6 \mathrm{TWh}$ [5]. The developing countries, including China, India and other Asian countries, account for nearly half of this substantial growth rate in renewable power generation [3]. It is projected that the share of renewable sources in the global primary energy will reach around $15 \%$ by 2040 from $4 \%$ today [3].

Turkey's high rate of economic growth leads to equally high rate of increase in the primary energy production and consumption [6]. This also equally translates into increase in Turkey's power generation 
capacity, mainly electricity. However, Turkey has only limited indigenous fossil fuel reserves, meaning that the amount of fossil fuel import has to increase to be able to satisfy the deficit of energy. As a result of this imbalance between the fossil fuel production and consumption, Turkey should turn to alternative energy sources, mainly to renewable energy sources, solar and wind energies being the main candidates.

\section{WORLD ENERGY STATISTICS}

Together with the increase in population, the acceleration of industrialization in the past century led to an exponential growth in energy consumption. While the world population was 1.6 billion in $1900 \mathrm{~s}$, the total primary energy consumption was approximately 1100 Mtoe [7]. In 2000s, the world population increased by 3.8 times to 6 billion, meanwhile, primary energy consumption increased by 8.5 times to 9285 Mtoe [8]. While 8089 Mtoe of this energy was met from fossil resources such as oil, natural gas and coal, the remaining 610 Mtoe was met from hydraulic energy and 584 Mtoe from nuclear energy [7,8]. The global primary energy supply between 2008 and 2018 are presented in Figure 1. As can be seen in Figure 1, the global consumption of primary energy increased to 13865 Mtoe as of 2018, growing $2.9 \%$ compared to the previous year [3,5,9]. From Figure 1, except for a decrease in 2009, the global energy supply increased steadily between the years from 2008 to 2018. The annual average growth rate of the global energy supply was \%1.7, taking into account the years from 2008 to 2018.

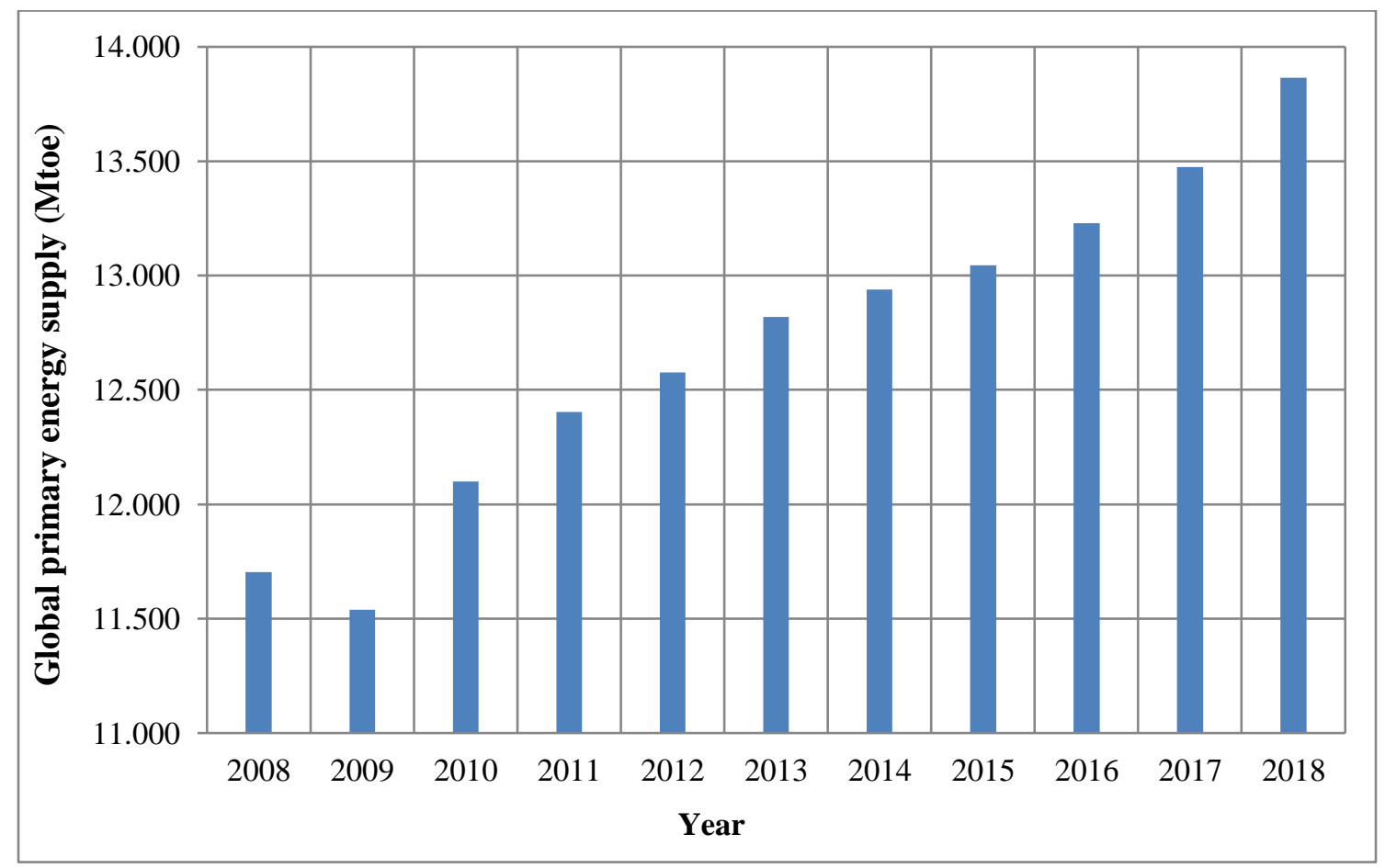

Figure 1. Global primary energy supply between 2008 and 2018 [5].

Primarily led by China and India, the vast majority of the increase in power demand originates from the developing countries as the demand growth in the developed economies, including the OECD, is significantly smaller. The global energy demand is expected to increase between 20 and $35 \%$ by 2040 according to various scenarios developed by the BP. It is predicted that the developing countries will contribute most to this increase due to potential changes such as fast industrial and infrastructural developments and the increasing living standards [3]. It should be added that while countries need to increase or sustain their power generation, however, this cannot be realized without complying with restrictions stipulated by the international environmental agreements such as the Paris Agreement. Therefore, countries need to implement such policies that will enable them to achieve a low carbon footprint in the energy conversion processes. Parallel to this, according to one of BP's scenarios named the 'evolving transition', it is expected that renewables and natural gas will meet as much as $85 \%$ of the 
annual primary energy growth. The 'evolving transition' is developed based on the assumption that the dynamics behind the energy policies such as the government policies, technologies and societal preferences will continue as before [10]. It should be noted that the 'evolving transition' takes a more moderate view compared to the other scenario of BP namely "rapid transition". On the other hand, the latter assumes a more aggressive transition to a low carbon era by swiftly adopting actions required such as the incentives, tariffs, and investments in such clean technologies [3].

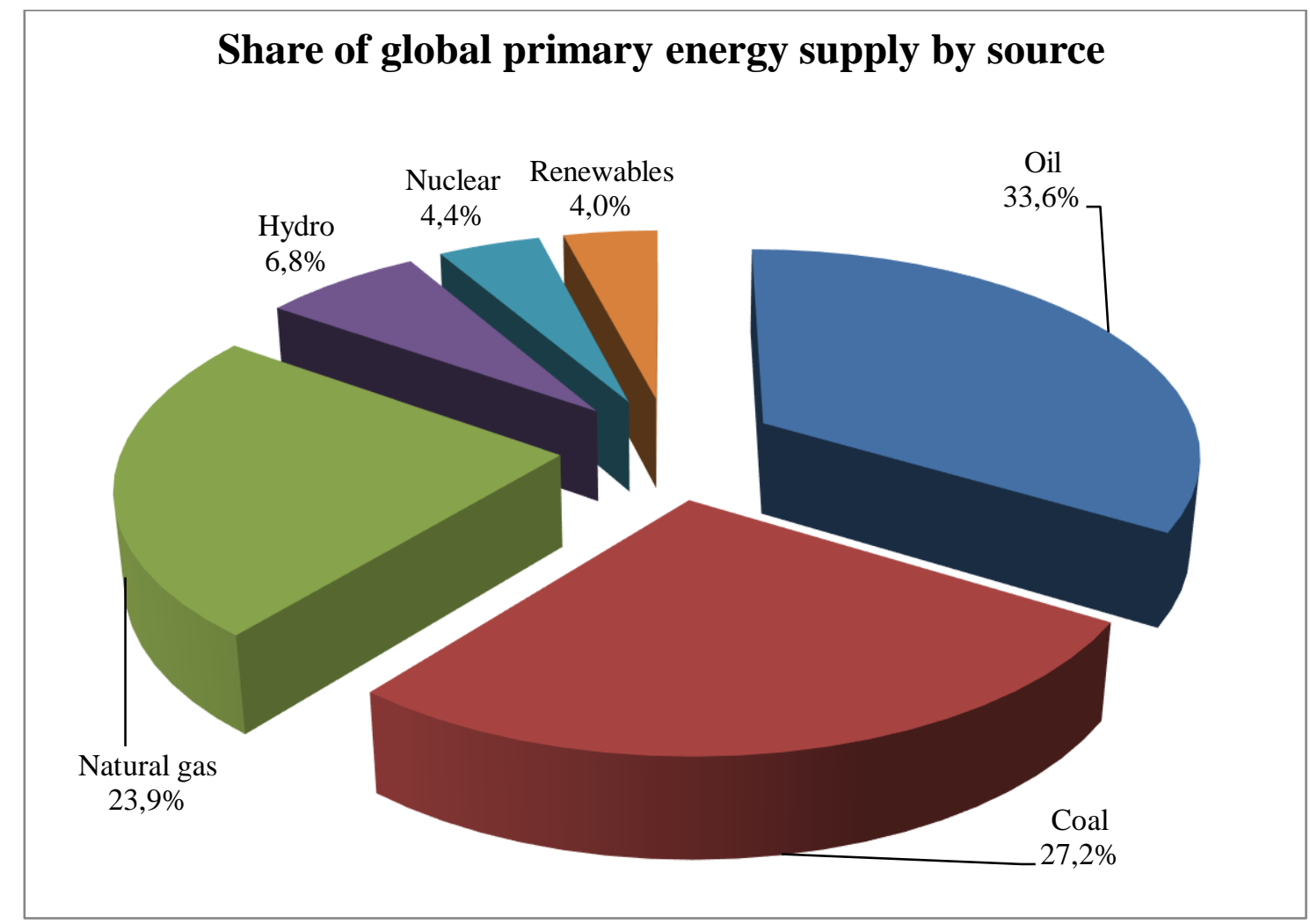

Figure 2. Source shares of primary energy supply for 2018 in the world [5].

The distribution of the global primary energy supply by source is given in Figure 2. As it is shown in Figure 2, in today's world, oil, natural gas, and coal are still notably dominant, constituting $84.7 \%$ of the primary energy consumption in 2018. According to the source shares of primary energy supply in Figure 2, oil has the largest share with a ratio of $33.6 \%$ [5]. It is followed by coal with $27.2 \%$ and natural gas with $23.9 \%$. These data verify that fossil fuels will continue to dominate the energy balances for years to come. China, which is the most populous country in the world, has seen a big growth in its energy supply/consumption due to rapid industrialization. China consumes $23.6 \%$ of the world's primary energy source alone corresponding to 3273.5 Mtoe. China is followed by the USA with 2300.6 Mtoe, which corresponds to $16.6 \%$ [5].

The global installed power capacity is around $7150 \mathrm{GW}$ as of 2018 [11]. The source with the highest installed power is coal with approximately $2100 \mathrm{GW}$ of global capacity, followed by natural gas with about $1750 \mathrm{GW}$ capacity. Hydro sources, renewables, oil and nuclear energy have a global installed power capacity of $1270 \mathrm{GW}, 1181 \mathrm{GW}, 450 \mathrm{GW}$ and $392 \mathrm{GW}$, respectively. The global electricity generation is currently $26614.8 \mathrm{TWh}$ of which $11233.6 \mathrm{TWh}$ is produced in OECD countries. Except for a $0.8 \%$ decrease in 2009 compared to the previous year, the average growth in the global annual electricity generation is $3.1 \%$ between the years 2008 and 2018. Between the same years, the total growth was 30.3\% from 20433.3 TWh in 2008 to 26614.8 TWh in 2018. As of 2018, 10100.5 TWh of the total generation was by coal, corresponding to $38.0 \%$. This is followed by natural gas with $23.2 \%$. Hydro sources contribute $15.8 \%$ to the global electricity generation. Nuclear energy and the renewables contribute $10.1 \%$ and $9.3 \%$, respectively, while the oil and the others have a share of $3.6 \%$. 


\section{A. GLOBAL RENEWABLE ENERGY STATISTICS}

One of the main motives of countries' preference towards renewable energy is the global warming. This is shown as the reason as to why renewable energy will have to provide most of the world's energy in future. It has been argued that a figure of $350 \mathrm{ppm}$ for $\mathrm{CO}_{2}$ in the atmosphere is considered as the safe 'planetary boundary' [1]. However, it was reported that the atmospheric concentration of $\mathrm{CO}_{2}$ has already passed $407 \mathrm{ppm}$ in 2018 [12]. On the other hand, it is generally acknowledged that the frequency of occurrence of extreme meteorological events have been increasing over the past decades [12]. Taking the $400 \mathrm{ppm}$ level as the safe limit, some researchers link these increasingly frequent extreme meteorological events to this high concentration of $\mathrm{CO}_{2}[12]$.

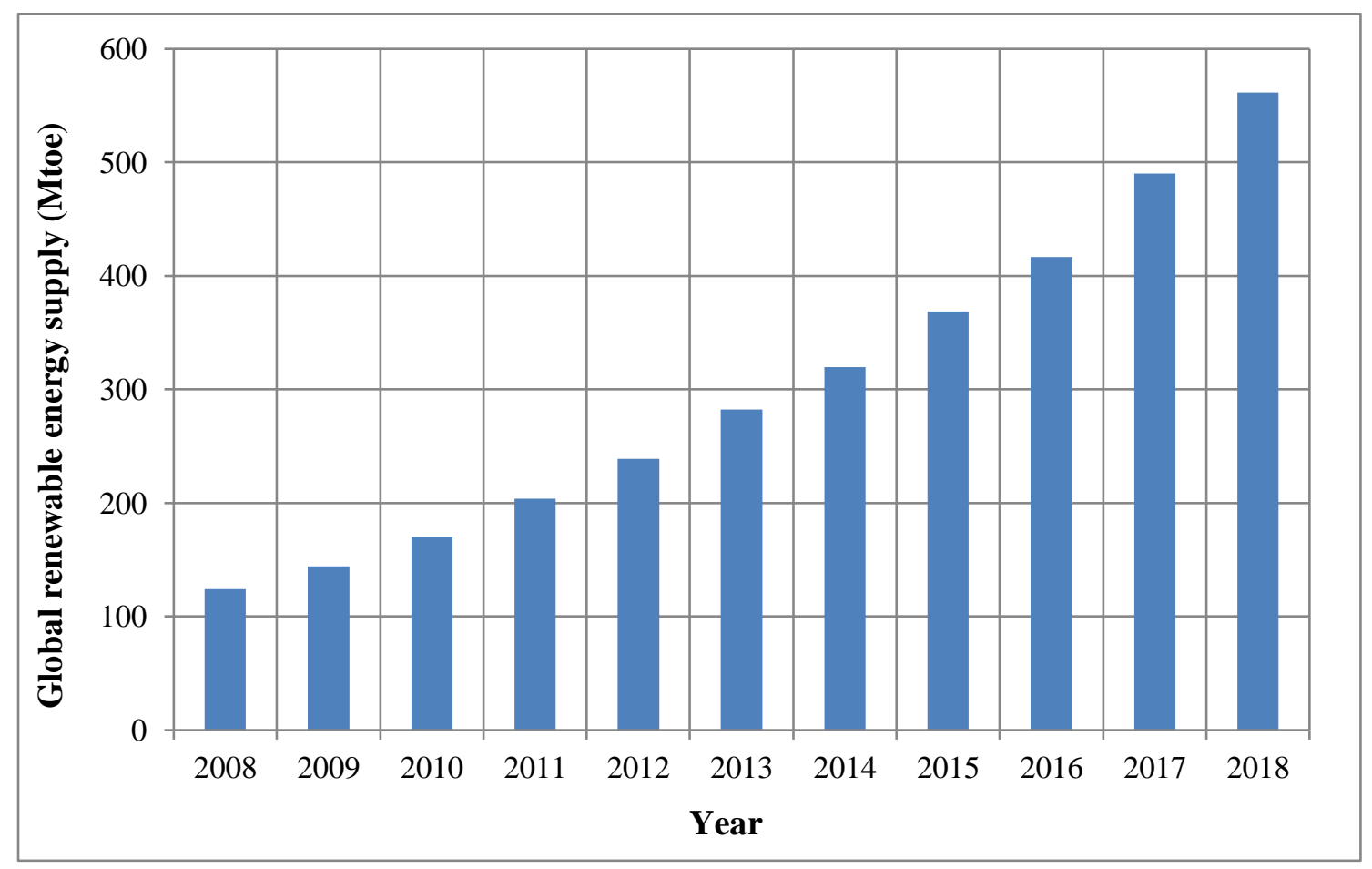

Figure 3. Global renewable energy supply between 2008 and 2018 [3,5].

As a result of the developments in renewable energy conversion technologies and countries' preference due to global warming, the share of renewable energy has been increasing steadily in recent years. As given in Figure 3, by the end of 2018, total renewable energy supply including wind and solar was 561.3 Mtoe [5]. In 2018, the renewable energy supply increased by $14.5 \%$ compared to the previous year [5,9]. The annual average increase in the renewable energy supply between the years 2008 and 2018 was $16.3 \%$ [5,13]. Regarding the renewable energy supply by country, China leads with 143.5 Mtoe as of 2018 [3,5]. It is followed by the USA with 103.8 Mtoe and Germany with 47.3 [3,5]. These figures clearly demonstrate that countries have steadily been increasing the share of renewable energy in their total energy supply.

The total installed renewable power in the world reached $1181 \mathrm{GW}$ as of 2018 , increasing by $8.01 \%$ compared to the previous year $[3,5]$. The source share of globally installed renewable electricity capacity as of 2018 is presented in Figure 4. Note that the globally installed hydroelectric power capacity was $1126 \mathrm{GW}$, which is not included in Figure 4. Amongst the renewable resources, wind holds the largest share with $563.7 \mathrm{GW}$, corresponding to $47.7 \%$ of the installed renewable capacity. In 2018, solar PV, which has the highest growth rate among all energy systems in the world, reached a capacity of 480.4 $\mathrm{GW}$, corresponding to $40.7 \%$, with an increment rate of $16 \%$ compared to the previous year $[3,5]$. Bioenergy has a capacity of $104.6 \mathrm{GW}$, corresponding to $8.9 \%$ of the global renewable capacity. The contribution of other renewable energy sources at the end of 2018 is as follows: geothermal was 13.3 GW and tide wave and ocean energy was $0.532 \mathrm{GW}[3,5]$. 


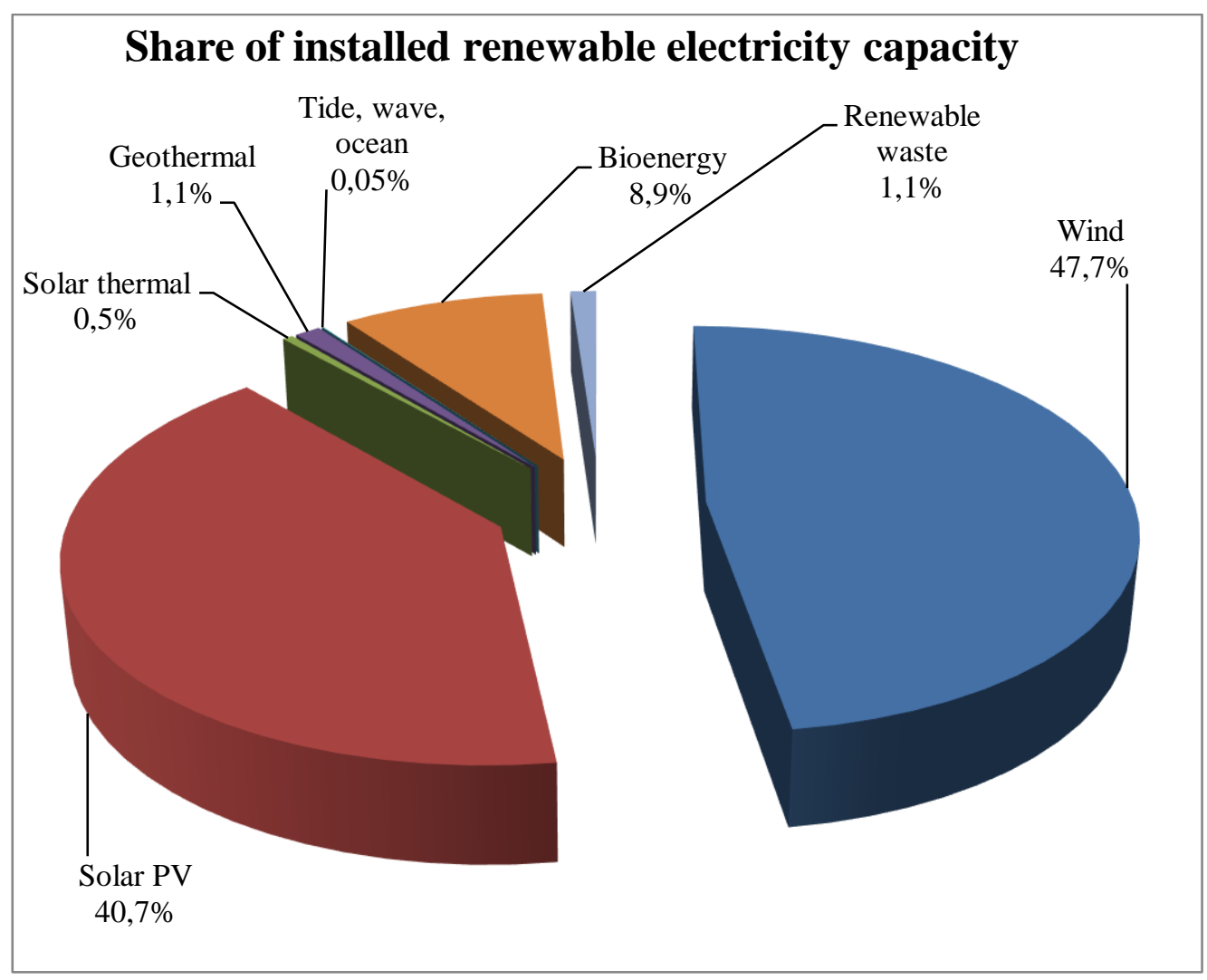

Figure 4. Source share of installed renewable electricity capacity [3,5].

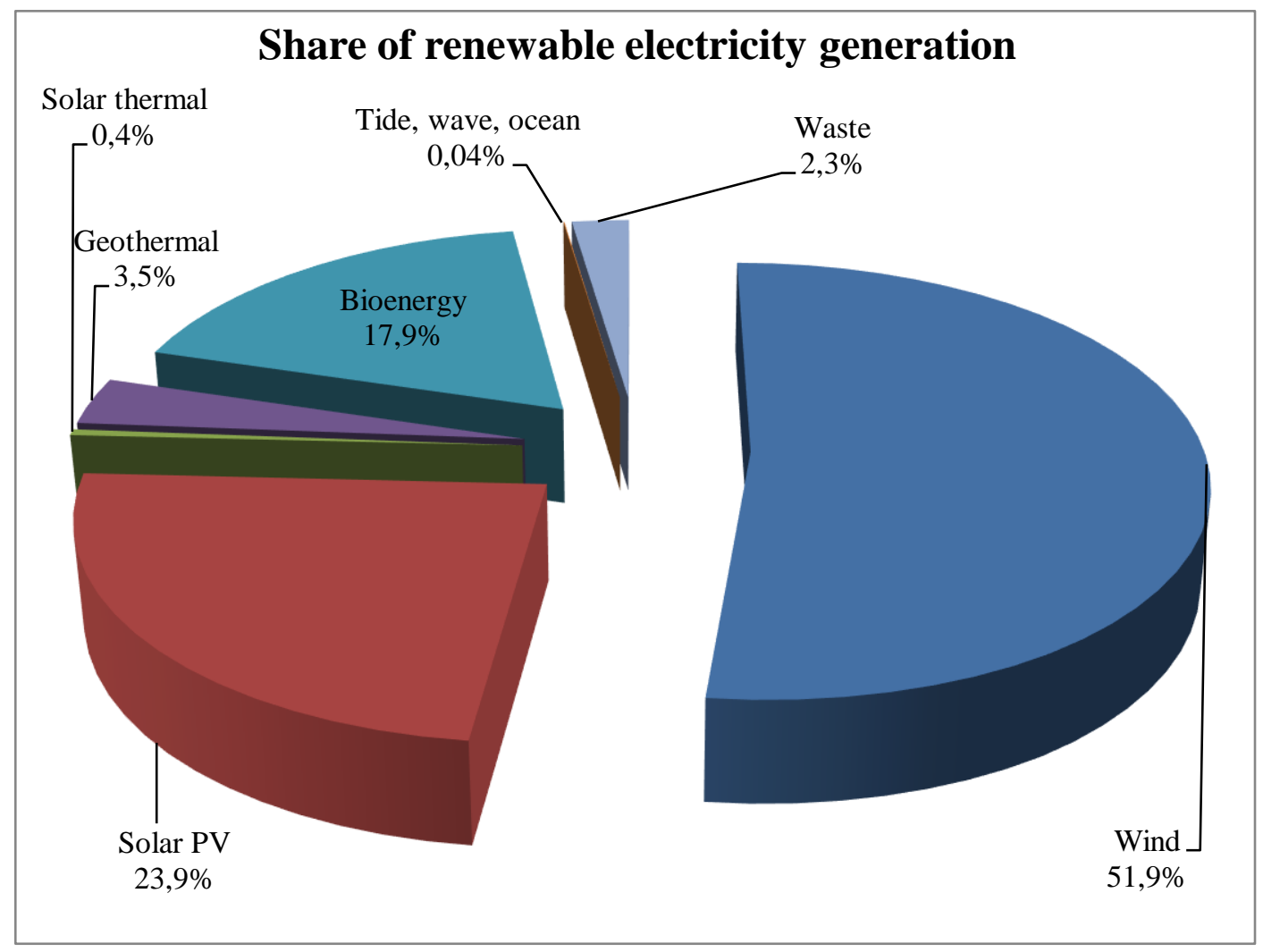

Figure 5. Source share of global renewable electricity generation in 2018 [3,5, 13]. 
Source share of global renewable electricity generation in 2018 is given in Figure 5. Total of $2447 \mathrm{TWh}$ electricity was generated in the world in 2018 by the renewable resources including wind, solar PV and thermal, geothermal, bioenergy, waste and tide, wave and ocean. Electricity generated globally by hydro resources reached 4197.3 TWh in the same year. As seen in Figure 5, nearly two thirds of the energy was generated by wind, amounting to 1270 TWh globally.

Electricity generation increased by $3.7 \%$ in 2018 compared to the previous year, China alone accounting for more than half of the growth, India and the US also contributing significantly. Renewable sources met one third of the increase in this year. In this year, $45 \%$ of this global renewable electricity generation growth came from China, which accounted for a higher contribution than that of the OECD [3,5]. Renewable electricity was closely followed by the electricity generated by coal (31\%) and natural gas (25\%). With this increase, the cumulative portion of renewable electricity rose from $8.4 \%$ to $9.3 \%$. Overall, however, coal continued to dominate its position cumulatively with $38 \%$ [5].

As shown, the statistics indicate that the renewables, dominated by the wind and solar, are significantly increasing their share when compared to the other energy sources of coal, nuclear and hydro. This clearly shows the inclination towards a more renewable future. In fact, even according to the moderate 'evolving transition' scenario of BP, with the present annual growth rate of $7.6 \%$, renewable electricity will make up a portion of two thirds of the increase in the global electricity generation so that, by 2040, it will take the lead as the electricity generation technology. In contrast, the share of fossil fuels in the global electricity generation will decline; coal, for example, will be overtaken by renewables as the main source of electricity by $2040[3,5]$.

\section{A. 1. Global Installed Photovoltaic Capacity}

At the end of 2018, the world's total renewable energy capacity excluding hydro reached $1179.15 \mathrm{GW}$ [3]. Of the total capacity $480.4 \mathrm{GW}$ was the PV power [5]. As of 2018, solar PV power constitutes $40.7 \%$ of the total installed power of renewable energy worldwide [5]. $263 \mathrm{GW}$ of the total $480.4 \mathrm{GW}$ installed power across the globe is on the Asian continent [12]. China has the largest installed PV power of this continent with $175 \mathrm{GW}$ [13]. Japan follows China with an installed power of 55.5 GW [13]. These two countries make use of their solar energy potential effectively. Asia is followed by Europe with an installed power of $115.3 \mathrm{GW}$, excluding Turkey [5]. Moreover, the total installed power of the EU countries is almost equal to that of Europe. Germany is the country that has the highest installed capacity in Europe with a total installed capacity of $45.2 \mathrm{GW}$ [5]. America has the third largest installed power with approximately $74 \mathrm{GW}$, constituting nearly one fifth of the global capacity [5]. The largest installed power in this continent is the United States with 62.2 GW [5]. The global PV electricity generation reached $443.6 \mathrm{TWh}$ as of 2018 , corresponding to $26.6 \%$ within the renewable resources.

\section{A. 2. Global Installed Wind Capacity}

Wind energy has been one of the fastest growing energy conversion systems in the world in the past few decades. The global wind electricity generation increased over 12 fold from 104 TWh to $1270 \mathrm{TWh}$ between the years 2005 and 2018. It is argued that if the present momentum is conserved and the renewable energy transition and wind energy diffusion continue to increase worldwide, wind energy will be responsible for savings of nearly 23 billion tonnes of $\mathrm{CO}_{2}$ by 2030, in addition to other benefits such as the creation of millions of new jobs [14].

The global installed wind capacity was $514.9 \mathrm{GW}$ at the end of 2017, generating a total of $1127 \mathrm{TWh}$ of electricity. The installed capacity reached $591 \mathrm{GW}$ at the end of 2018, the electricity generated reaching $1270 \mathrm{TWh}$ [5]. China has got far the highest installed wind capacity with $211.4 \mathrm{GW}$ followed by the US with $96.7 \mathrm{GW}$ as of 2018. On the other hand, in 2018, wind energy contributed most to the Danish electricity system, covering the equivalent of $40.7 \%$ of the Danish electricity consumption [15]. The installed wind capacity in Denmark rose to $5758 \mathrm{MW}$ in 2018 by an increase of $5.2 \%$ from the previous year of $5475 \mathrm{MW}$. 
In $2018,7.0 \%$ of the global electricity generation and a relatively smaller part of the primary energy supply came from solar and wind [5]. If wind and solar will increase their share in the total energy supply in future, energy storage on a large scale is seen as the most important challenge to be faced, especially since most energy will be produced as electricity. Therefore, cost-effective and efficient methods for energy storage on a large scale are required such as batteries, pumped water storage, compressed air energy storage, and conversion to hydrogen, either for direct use or storage for later use [16].

\section{ENERGY STATE OF THE EUROPEAN UNION}

Most EU countries largely fail to meet their energy needs from their own natural resources. In 2018, the EU (EU-27) generated only $41.8 \%$ of its energy, having had to import $58.2 \%$ of its energy need [17]. Due to the fact that the EU attaches importance to the security of energy supply, they aim to increase the diversity of its energy generation sources.

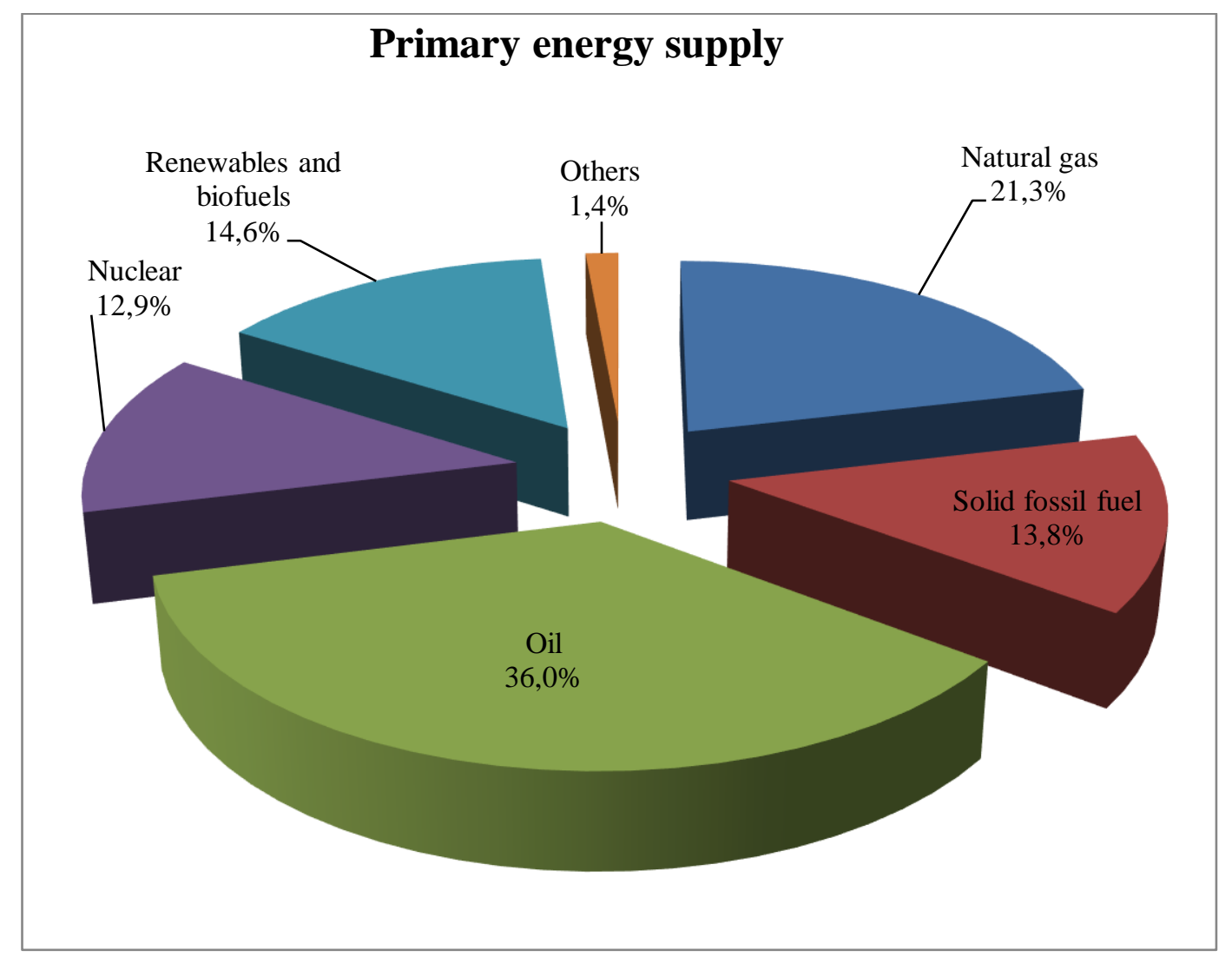

Figure 6. Share of primary energy supply of EU countries by source [18,19].

The share of primary energy supply by source in the EU in 2018 is shown in Figure 6. As of 2018, the energy portfolio of the EU largely included the following energy resources; as the primary source, petroleum products were at the forefront with $36.0 \%$, including the crude oil. It is followed by natural gas with $21.3 \%$, solid fossil fuels with $13.8 \%$, renewables and bioenergy with $14.6 \%$ and nuclear with $12.9 \%$. As for the same year, the share of fossil fuels in gross available energy in the EU was $72.5 \%$.

The share of final energy consumption by source for individual member countries varies according to their natural energy potentials $[18,19,20]$. The member countries having the largest share of oil within the total energy consumption are; Cyprus with the rate of 93\%, Malta with 79\% and Luxembourg with $63 \%$. In Italy and the Netherlands natural gas constitute one-third of the total energy consumption. In Estonia, where fossil fuels are the main source of energy, $61 \%$ of total energy is supplied from coal. It 
is followed by Poland with a rate of $49 \%$. While nuclear power meets $42 \%$ of France's energy needs and $33 \%$ of Sweden's, Lithuania and Sweden are the countries with highest rates of renewable energy share in their total energy consumption, each with $37 \%$.

The share of energy generation by source also varies significantly within member countries [18,19,20]. For instance, nuclear power constitutes $80 \%$ of total electricity generation in France. Regarding nuclear energy, France is followed by Belgium (75\%) and Slovakia (62\%). Renewable energy, which holds the second largest share in the energy generation of the EU, is the primary energy source of most member countries such that it constitutes $90 \%$ of the total primary energy generated in Malta, Latvia, Portugal, Cyprus, and Lithuania. The leading member countries generating energy from fossil fuels are Poland with the rate of 78\%, Estonia with 67\% and Greece and the Czech Republic with 59\%, each. 83\% of the energy generated in the Netherlands is by natural gas while crude oil meets a significant proportion of energy demand with a rate of $47 \%$ in Denmark.

When the types of fuel used to generate electricity in the EU are examined; it is seen that fossil fuels have a $44 \%$ share in total $[18,19,20]$. This is followed by renewable energy with a rate of $30 \%$ and nuclear energy of $26 \%$. The rate of $30 \%$ for renewable energy includes the followings: hydroelectric power plants with $12 \%$, wind power plants with $9 \%$, bioenergy with $6 \%$, solar power plants with $3 \%$.

\section{A. ENERGY IMPORTS OF THE EU}

As stated before, the EU countries have to import from third countries in order to meet their energy needs. According to the 2018 figures, oil constitutes almost two thirds of the energy imports of the EU $[17,21,22]$. This is the most significant indicator of the fact that oil is an important energy resource across the world and also that countries cannot break oil dependence yet for some years to come. Oil is followed by natural gas with a $24 \%$ share and solid fuels with $9 \%$.

The EU countries import the energy from various countries. For ensuring the security of energy supply, the EU countries import the same commodity from different countries at different rates [17,21,22]. The EU countries import crude oil from 11 different countries. This is a key indicator of how much EU countries attach importance to the security of supply. Russia holds the largest share with a rate of $31 \%$ among the countries from which EU countries import oil [21]. Russia provides $30 \%$ of the solid fuel imports of the EU, being the largest importer of natural gas and solid fuel to the EU countries [22]. In spite of the strong mindset for the security of energy supply, it is clear that the EU is hugely dependent on Russia in oil, solid fuel, and natural gas supply [21,22]. The second largest share of energy exported to the EU is held by Norway. Norway has a significant share of oil and natural gas imports to the EU countries. The dependence on energy imports has increased by almost 50\% in the EU since 2000 [20]. The dependence on energy imports also differs for individual member states within the EU. For instance, while imports are about 90\% in Malta, Luxembourg, and Cyprus, it is less than 20\% in Denmark and Estonia [17].

\section{B. ENERGY CONSUMPTION OF THE EU}

Around two-thirds of the energy is consumed by end users in the EU countries [23-26]. This two-thirds rate includes electricity which is mostly used in dwellings and industry. When the ultimate energy consumption shares of the EU countries are examined closely, it is seen that the sectoral consumption shares are as follows: the industry with $31 \%$, transportation with $28 \%$, housing with $25 \%$, services with $13 \%$ and agriculture and forestry with $2 \%$. The remaining includes mainly the transmission loss.

Oil constituted nearly one-third of the total energy consumption of the EU countries in 2018 [25]. In Cyprus, Malta, and Luxembourg, the petroleum products met more than $60 \%$ of their total energy consumption. The countries of which shares of renewable energy exceeded $20 \%$ of the total ultimate consumption were Latvia, Finland, and Sweden. 


\section{RENEWABLE ENERGY CAPACITY AND DEVELOPMENT IN THE EU}

Despite the fact that the energy consumption of the EU countries is largely dependent on fossil fuels, however, there is a strong will and intense effort for the development of renewable energy to increase its share in energy consumption. This is substantiated by the fact that the renewable energy share in total energy consumption in the EU nearly doubled from 8\% to 15\% between the years 2000 and 2018 [19]. During this period, 15 member countries doubled their renewable energy share.

The EU aims that the share of renewable energy in total energy consumption is $20 \%$ by 2020 [13]. However, this target rate varies amongst the EU member states. For instance, Sweden provides 53.8\% of its energy consumption from renewable resources and has already achieved the 2020 target [20]. Similarly, Finland follows Sweden by a rate of $38.7 \%$ and has also reached its 2020 target [20]. The share of renewable energy in total energy consumption is $5.4 \%$ in Luxembourg, having the lowest share among the EU countries [19]. This difference within the renewable energy generation amongst the EU member states is largely caused by the share of hydroelectric power plants [20].

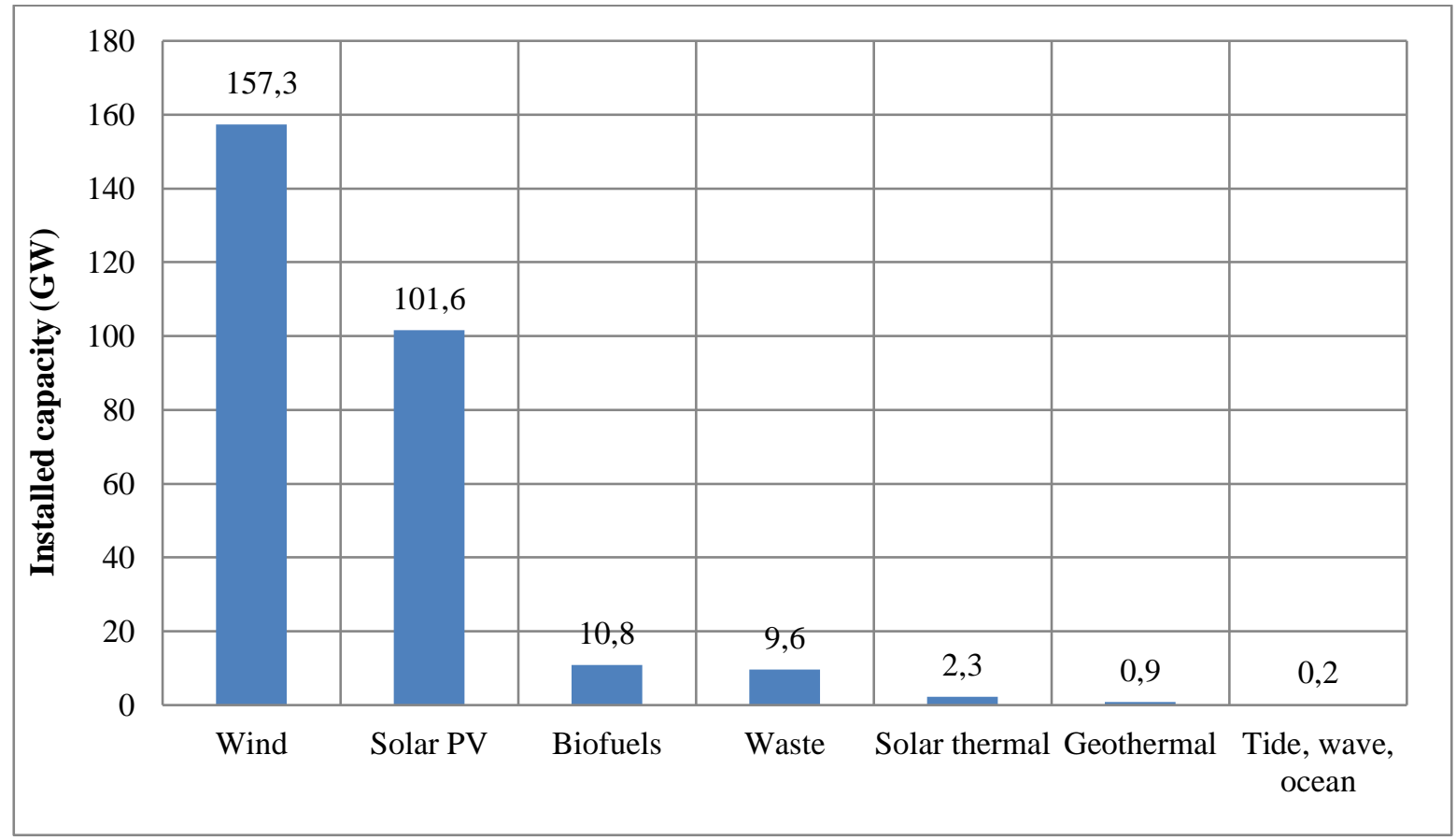

Figure 7. Installed renewable energy capacity of the EU by source [27]. 


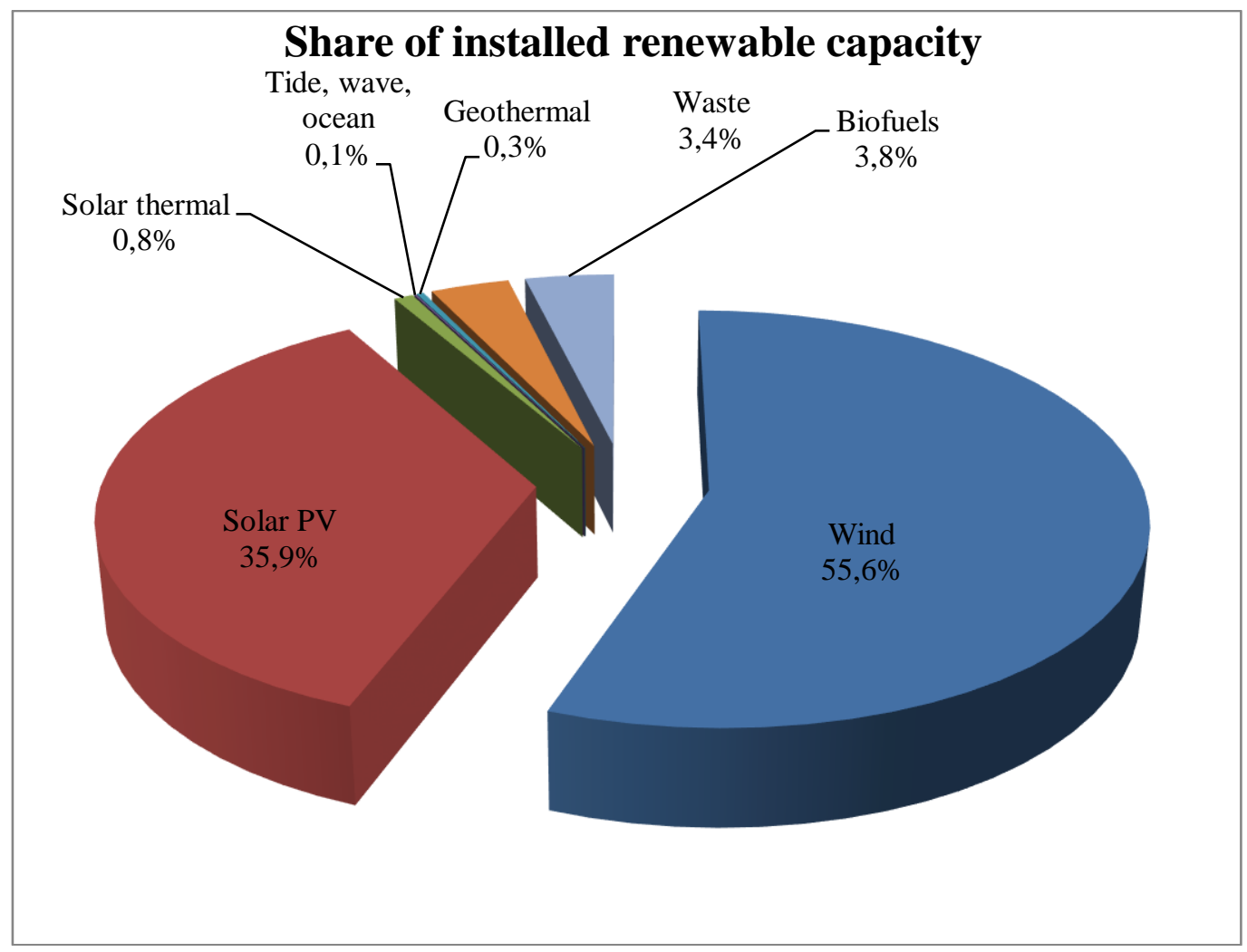

Figure 8. Share of installed renewable energy capacity of the EU by source [27].

The installed renewable energy capacity in the EU as of 2018 is presented in Figure 7 by source. The share of installed renewable energy capacity by source in the EU is given in Figure 8 for the same year. As of 2018, the installed renewable energy capacity in the EU reached $282.7 \mathrm{GW}$, excluding hydroelectric power capacity. As seen in Figure 7, the wind power is leading, having the largest share of renewable energy capacity in the EU with $157.3 \mathrm{GW}$. The total installed solar PV capacity reached $101.6 \mathrm{GW}$ by the end of 2018 in the EU, corresponding to more than one-third of the total installed renewable capacity. From Figure 8, wind power systems have the largest share within the renewable systems with 55.6\%, followed by the solar PV with 35.9\%. Bioenergy and waste have $10.8 \mathrm{GW}$ and 9.6 $\mathrm{GW}$ of installed capacity, each corresponding to $3.8 \%$ and $3.4 \%$ share in the installed renewable power in the EU. Tide, wave and ocean and geothermal have miniscule amounts of power capacities. The EU's leading position in terms of the penetration of renewables within the total power capacity is expected to continue as the share of renewables in the EU power market is predicted to reach 50\% by 2040 [3].

\section{TURKEY'S ENERGY STRUCTURE}

Turkey's net energy import was 443 billion USD between the years 2006 and 2017 period. Of which, 149 billion USD, corresponding to $30 \%$, was spent on the electric power production using fossil fuels [28]. Even though Turkey has got relatively high potential of wind and solar energy, however, it was unable to exploit this potential fully. As was given above, although Turkey imported billions of USD worth of fossil fuel for electricity generation, however, it was using $13 \%$ of its $49 \mathrm{GW}$ of economical wind power potential and only $1.3 \%$ of its $254 \mathrm{GW}$ solar power potential as of the end of 2017 [28]. It is obvious that for Turkey in order to lessen the burden of energy import on its budget deficit and avoid the potential economic risks, it must take the necessary steps to systematically reduce its dependency on imported fossil fuel. For not having enough indigenous fossil reserves, Turkey must adopt a more aggressive energy policy to make a better use of its high potential of wind, solar and other renewable energy resources.

The annual total energy supply of Turkey was 153.5 Mtoe in 2018, oil being the largest contributor with 48.6 Mtoe [5]. Turkey's energy supply declined $0.7 \%$ in 2013 compared to the previous year. Except 
for this decrease, the average growth in the total energy supply of Turkey was $4.2 \%$ between the years 2008 and 2018. Between these years, the total growth is 52.3\% from 100.8 Mtoe in 2008 to 153.5 Mtoe in 2018. Between 2008 and 2018, the highest growth rate was in 2014 with 9.4\%. As of 2018, almost one third of the total energy supply of Turkey was by oil (31.6\%). Coal contribution corresponded to $26.5 \%$ with 42.3 Mtoe. This is followed by natural gas with 40.7 Mtoe with a share of $23.2 \%$. Hydro sources contributed $8.8 \%$ to the energy supply of Turkey. Renewables contributed 8.5 Mtoe with a share of $5.5 \%$.

\section{A. INSTALLED POWER}

The development of installed power in Turkey by years is presented in Figure 9. The total installed electric power of Turkey reached 88569.0 MW as of 2018. As can be seen in Figure 9, the installed power experienced a geometric growth, nearly doubling in every ten-year period between 1976 and 2018. It is interesting to note that the installed capacity increased by a factor of 2.2 times between the years 2006 and 2018 from 40564 MW to 88569 MW. The main reasons for such a high increase in electricity demand are high rate of population and economic growth.

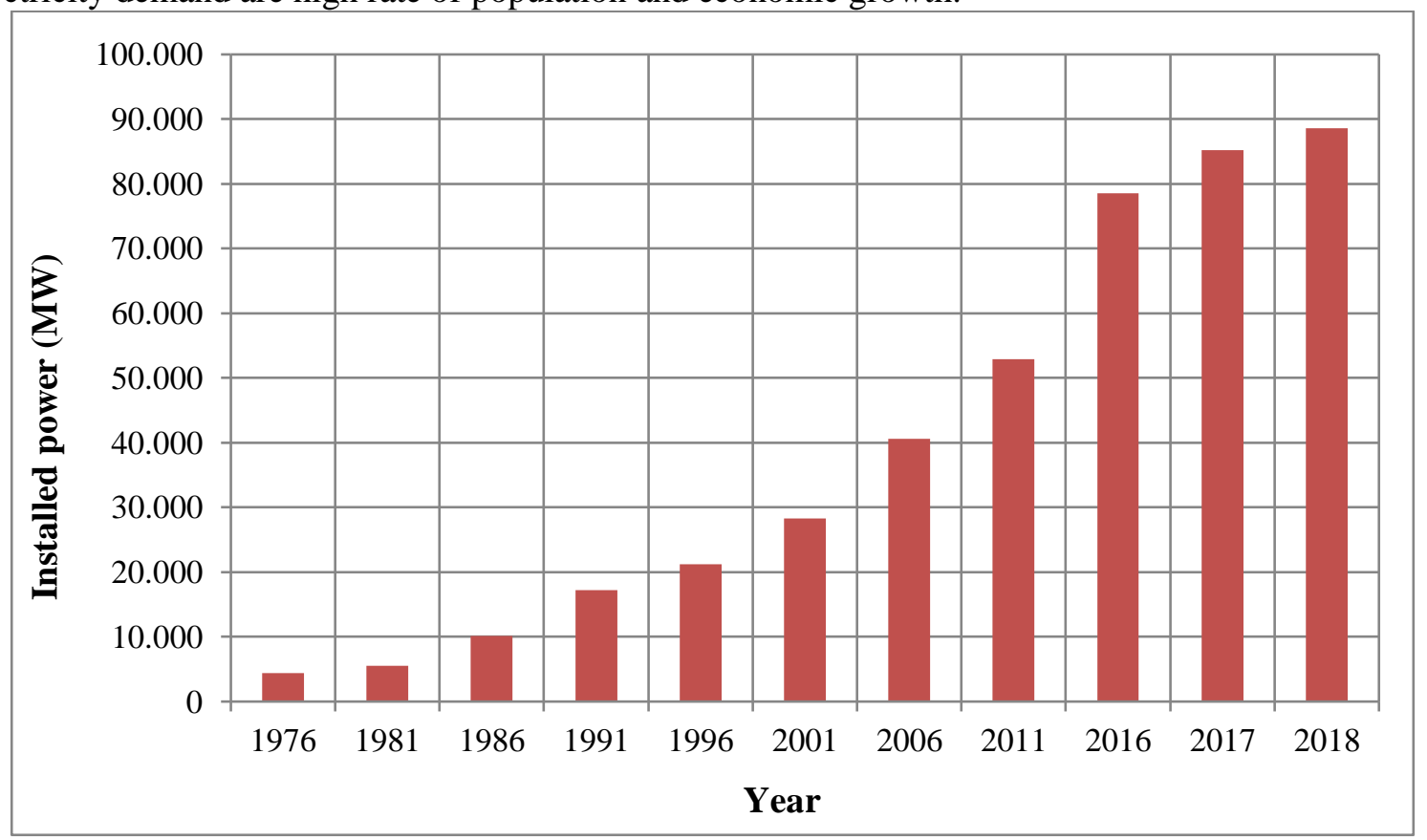

Figure 9. Development of installed power in Turkey by years [30].

Table 1. Source share of total installed power in Turkey from 2016 to 2018 [30,31].

\begin{tabular}{ccccccc}
\hline $\begin{array}{c}\text { Installed } \\
\text { Power }\end{array}$ & Fossil Fuel & Hydroelectric & Geothermal & Wind & Solar PV & Total \\
\hline 2016 & 44411.6 & 26681.1 & 820.9 & 5751.3 & 832.5 & 78497.4 \\
\hline$\%$ & 56.6 & 34.0 & 1.0 & 7.3 & 1.1 & 100 \\
\hline 2017 & 46926.5 & 27273.1 & 1063.7 & 6516.2 & 3420.7 & 85200.2 \\
\hline$\%$ & 55.1 & 32.0 & 1.2 & 7.60 & 4.0 & 100 \\
\hline 2018 & 46970.0 & 28248.0 & 1282.0 & 7005.0 & 5064.0 & 88569.0 \\
\hline$\%$ & 52.9 & 31.9 & 1.5 & 8.0 & 5.7 & 100 \\
\hline
\end{tabular}

The source share of total installed power in Turkey from 2016 to 2018 is given in Table 1 . The installed capacity increased by a factor of $12.8 \%$ between the years 2016 and 2018 from 78497 MW to 88569 
MW. As of 2018, the fossil fuel power plants, including natural gas, coal, biofuel and fuel oil constituted more than half of the installed power in Turkey. However, their share tends to decline slowly in recent years, from $56.6 \%$ in 2016 to $52.9 \%$ in 2018 . The largest share belongs to natural gas power plants within the fossil fuel power plants with $26568 \mathrm{MW}$, corresponding to $56.7 \%$ within this category. Fossil fuel based power plants are followed by the hydroelectric power plants, which represent almost one third of the installed power in Turkey. Wind power continues its gradual rise while solar PV plants experienced an exponential growth increasing nearly 6 times within 3 years, finally reaching $5064 \mathrm{MW}$ at the end of 2018.

\section{B. GENERATION OF ENERGY}

The annual electricity generation of Turkey between 2006 and 2018 is given in Figure 10. In 2018, gross electricity demand increased by nearly $3 \%$ in Turkey compared to the previous year and reached 304200 $\mathrm{GWh}$. In response to this demand, while total national production was $303625 \mathrm{GWh} ; 2477 \mathrm{GWh}$ electricity was imported to meet the energy deficit in 2018. Turkey imported electricity from neighbouring countries; Bulgaria with $2051 \mathrm{GWh}$, Georgia with $494 \mathrm{GWh}$, Turkmenistan with 161 GWh and Greece with 0.5 GWh [32]. The electricity generation increased by $72.2 \%$ between the years analysed in Figure 5. Electricity generation by resource and their share in total electricity generation in Turkey as of 2018 are presented in Table 2. It is seen that a major share of the electricity generation belongs to fossil fuel based power stations with $69 \%$, corresponding to $209605 \mathrm{GWh}$. The largest share is produced by coal fired power stations with $113249 \mathrm{GWh}$, corresponding to $37 \%$ in total generation. Hydroelectric power stations generate $19.7 \%$ of the total electricity, corresponding to $59755 \mathrm{GWh}$.

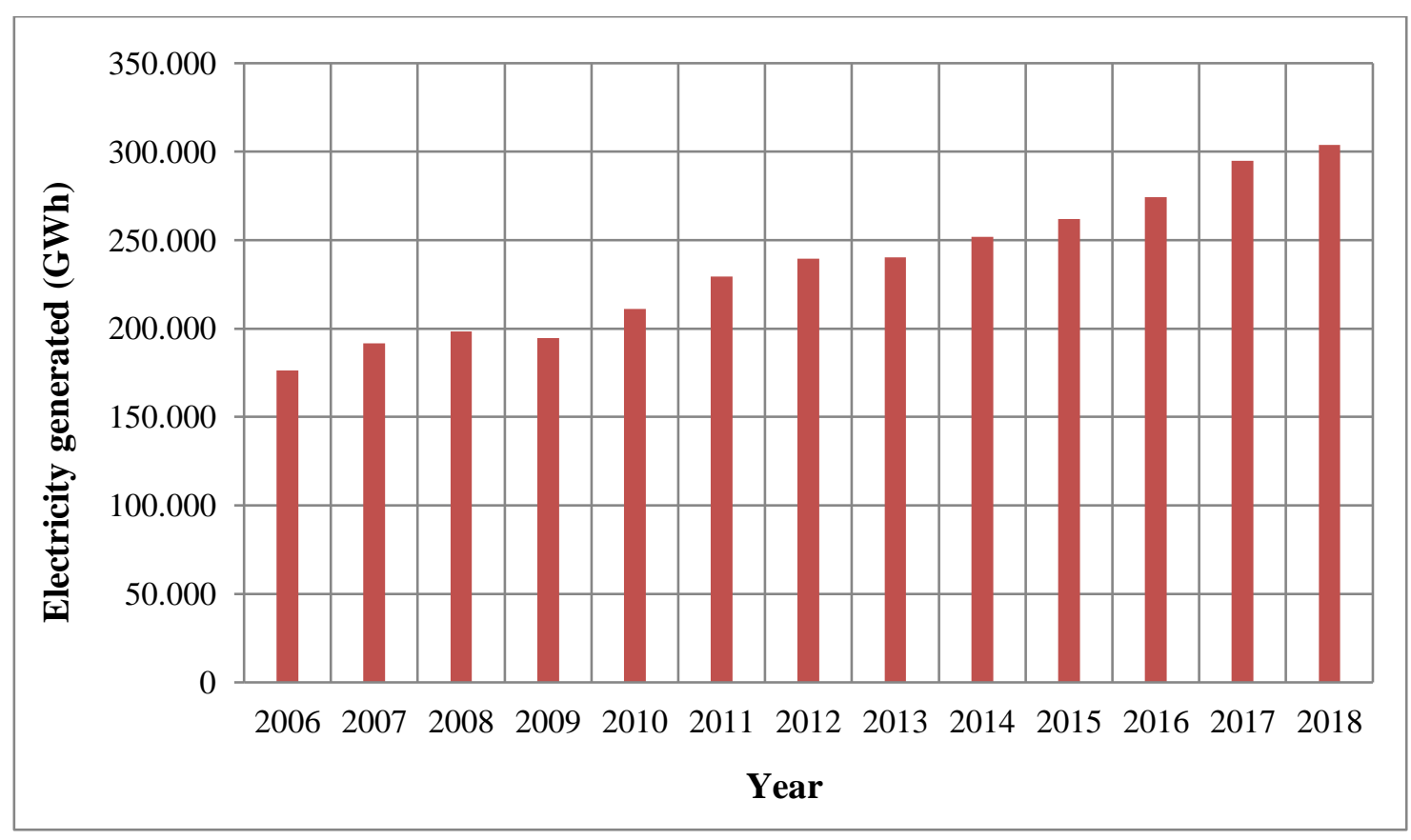

Figure 10. Annual electricity generation of Turkey between 2006 and 2018 [32]. 
Table 2. Electricity generation by resource and their share in total electricity generation in Turkey as of 2018 [32].

\begin{tabular}{ccc}
\hline Resource & $\begin{array}{c}\text { Electricity generation } \\
(\mathrm{GWh})\end{array}$ & $\begin{array}{c}\text { Contribution } \\
(\%)\end{array}$ \\
\hline Fossil Fuel & 209605 & 69.0 \\
\hline Hydro & 59755 & 19.7 \\
\hline Geothermal & 6906 & 2.3 \\
\hline Wind & 19882 & 6.5 \\
\hline Solar PV & 7477 & 2.5 \\
\hline Total & 303625 & 100 \\
\hline
\end{tabular}

The number of renewable-based power stations and their installed capacities are presented in Table 3 for Turkey as of 2018. According to this table, within the renewable category, hydroelectric power stations have both the highest number and also present the largest installed capacity with 641 stations and $28248 \mathrm{MW}$. In terms of the installed capacity, hydroelectric stations are followed by wind power stations with a total installed capacity of $7005 \mathrm{MW}$.

Table 3. Number of renewable-based power stations and their installed capacities for Turkey as of $2018[31,33]$.

\begin{tabular}{ccc}
\hline Resources & Number of Facilities & Installed Capacity (MW) \\
\hline Hydroelectric & 641 & 28248 \\
\hline Wind & 192 & 7005 \\
\hline Geothermal & 48 & 1303 \\
\hline Biomass, biogas, & 100 & 646 \\
\hline Solar PV & 564 & 5064 \\
\hline
\end{tabular}

As per the targets for 2023 in Turkey, the expansion of renewable energy in the electricity sector has been planned within the framework of "National Renewable Energy Action Plan" as given in Table 4. It is interesting to note that for solar PV the 2023 target of $5000 \mathrm{MW}$ has already been achieved as of 2018. The same is also true for the biomass. It is realised that the largest gap is for the wind energy, where the deficiency is nearly twice that of the present installed capacity. Therefore, in order for Turkey to reach the targets set for 2023, the efforts should be increased significantly.

Table 4. The installed capacity targets for 2023 by source according to Turkey's "National Renewable Energy Action Plan" [34,35].

\begin{tabular}{cc}
\hline Resource & Installed Capacity Targets (MW) \\
\hline Hydro & 34000 \\
\hline Wind & 20000 \\
\hline Geothermal & 1000 \\
\hline Biomass & 1000 \\
\hline Solar & 5000 \\
\hline
\end{tabular}

The predicted annual electricity consumption per capita for Turkey is shown in Table 5 for various years. Note that the average electricity consumption per capita of 29 IEA member countries was $9900 \mathrm{kWh}$ in 2016 while that of Turkey was about $3500 \mathrm{kWh}$. Therefore, Turkey is not expected to reach the average 
of IEA members' electricity consumption per capita in the near future. In order to reach the economic level of developed countries, Turkey should aim not only to rapidly increase its electricity consumption per capita but also to increase its energy conversion efficiency [35].

Table 5. Predicted annual electricity consumption per capita for Turkey [35].

\begin{tabular}{cc}
\hline Year & Target Energy Consumption Per Year \\
\hline 2020 & $4800-5000 \mathrm{kWh}$ \\
\hline 2023 & $5550-6000 \mathrm{kWh}$ \\
\hline 2030 & $>7000 \mathrm{kWh}$ \\
\hline 2040 & $>8000 \mathrm{kWh}$ \\
\hline
\end{tabular}

\section{PV AND WIND DEVELOPMENT}

The concept of sustainability has gained a central place in many aspects of macro policies for countries, including energy policies mainly due to economic and environmental reasons. Therefore, energy policies are being revised and renewable energy technologies are increasing their presence in the future energy policies of countries throughout the world and in Turkey also. Parallel to this policy adoption in Turkey, it has been shown that the renewable electricity share has been gradually increasing over the past decade in Turkey even though the share within the total electricity generation is still relatively low with $11.3 \%$, excluding hydroelectricity, as of 2018. However, as has been already stated, Turkey needs a faster transition to more renewable and sustainable energy infrastructure not only for a better energy security and greater diversification in the energy mix but also for a more competitive economy [29].

Due to its geographical location with relatively high solar energy, Turkey on average receives 2737 hours of solar radiation annually, corresponding to 7.5 hours of daily radiation, according to GEPA. The yearly total solar energy received in Turkey is $1527 \mathrm{kWh}$ on average per unit area, being equal to a daily amount of $4.2 \mathrm{kWh} / \mathrm{m}^{2}$ [36]. Considering the solar energy potential of Turkey, it was projected that an annual amount of solar energy equal to 380 billion $\mathrm{kWh}$ could be possible as a primary energy [38].

The total installed power of licensed solar plants was $12.9 \mathrm{MW}$ as of 2016 , increasing to $17.9 \mathrm{MW}$ at the end of 2017 [31]. The installed power of unlicensed plants was 819.6 MW by the end of 2016, corresponding to $1 \%$ of Turkey's total installed power. This reached $3402.8 \mathrm{MW}$ as of 2017, which was $4 \%$ of the total installed power [31,33]. Electricity generation from the solar power plants was 2430 GWh in 2017 [30]. As of 2018, the cumulative PV capacity reached $5065 \mathrm{MW}$ and the total number of facilities was 564, of which 15 with license and the remaining number unlicensed. Electricity produced from the solar power systems reached $7477 \mathrm{GWh}$ by the end of 2018 [31].

The principal reasons that the number of licensed solar power plants is just a fraction of the number of unlicensed plants in Turkey are as follows: bureaucratic difficulties in obtaining a license, length of the processes for permits and bureaucratic transactions, costs, lack of coordination between the institutions involved, and difficulties encountered while collecting the fees of surplus electricity sold to the distribution companies. Licensed electricity generation is an important production instrument in terms of energy development and policy for Turkey due to the fact that the producer is in an advantageous position in terms of electricity sales prices, and it is a promising investment thanks to the open price system or YEKDEM price regulation.

With regard to the wind energy development, the cumulative wind capacity reached $7005 \mathrm{MW}$ as of 2018 in Turkey. This is $8 \%$ of the total installed power of Turkey and only $14 \%$ of Turkey's technical wind power potential of $49 \mathrm{GW}$ [28]. The highest annual installation took place in 2016 with $1388 \mathrm{MW}$. The amount of electricity produced from wind was $19882 \mathrm{GWh}$ in 2018 , corresponding to a ratio of $6.5 \%$ of the total electricity generation of Turkey. The installed wind energy capacity grew almost 20 fold between the years 2008 and 2018, corresponding to an average annual growth of $37 \%$ [39]. 


\section{CONCLUSION}

Fossil fuels being the major contributors, the present primary energy use has increased nearly 30 times since the 1800s. The global primary energy use reached 13865 Mtoe as of 2018, particularly accelerating in 1950s. Nearly $80 \%$ of the energy presently used globally is still provided from fossil fuel sources. The principal fossil fuel sources are oil, coal and natural gas, with the shares $32 \%, 27 \%$ and $22 \%$, respectively. Global primary energy supply grew by 390 Mtoe in 2018, while renewable energy supply by 71 Mtoe in the same year, corresponding to $2.9 \%$ and $14.5 \%$ increase compared to the previous year, respectively. Primarily led by China and India, vast majority of the increase in power demand originates from the developing countries as the demand growth in the developed economies, including the OECD, is significantly smaller. The global energy demand is expected to increase between 20 and $35 \%$ by 2040 according to various scenarios developed by the BP.

The global installed power capacity is around $7150 \mathrm{GW}$ as of 2018 . The source with the highest installed power is coal with approximately $2100 \mathrm{GW}$ of global capacity, followed by natural gas with about 1750 GW capacity. Hydro sources, renewables, oil and nuclear energy have a global installed power capacity of $1270 \mathrm{GW}, 1181 \mathrm{GW}, 450 \mathrm{GW}$ and $392 \mathrm{GW}$, respectively. The installed capacity of renewable energy (excluding hydro) increased 8\% compared to the previous year. Amongst the renewable resources, wind holds the largest share with $563.7 \mathrm{GW}$, corresponding to $47.7 \%$ of the installed renewable capacity. Wind is closely followed by solar PV with $480.4 \mathrm{GW}$, constituting $40.7 \%$ of the total installed power of renewable energy worldwide. The total installed capacity of bioenergy is $104.6, \mathrm{GW}$, corresponding to $8.9 \%$. The global capacity of hydroelectric power was realized as $1127 \mathrm{GW}$ as of 2018 . Total of 2447 TWh electricity was generated in the world in 2018 by the renewable resources including wind, solar, geothermal, bioenergy, waste and tide, wave and ocean. Wind electricity generation increased from 1128 TWh to $1270 \mathrm{TWh}$, growing by $12.6 \%$ in 2018 , providing approximately $45 \%$ of the renewable electricity growth in that year. Solar electricity generation grew by $29 \%$, increasing from 453.5 TWh to 584.6 TWh. The developing countries, including China, India and other Asian countries, account for nearly half of this substantial growth rate in renewable power generation. It is projected that the share of renewable sources in the global primary energy will reach around $15 \%$ by 2040 from $4 \%$ today.

Electricity generation increased by $3.7 \%$ in 2018 compared to the previous year, China alone accounting for more than half of the growth, India and the US also contributing significantly. Renewable sources met one third of the increase in this year. In $2018,45 \%$ of the global renewable electricity generation growth came from China, which accounted for a higher contribution than that of the OECD. Renewable electricity was closely followed by the electricity generated by coal (31\%) and natural gas (25\%). With this increase, the cumulative portion of renewable electricity rose from $8.4 \%$ to $9.3 \%$. Overall, however, coal continued to dominate its position cumulatively with $38 \%$.

As of 2018, the energy portfolio of the EU largely included the following energy sources; as the primary source, petroleum products were at the forefront with $36.0 \%$, including the crude oil. It is followed by natural gas with $21.3 \%$, solid fossil fuels with $13.8 \%$, renewables and biofuels with $14.6 \%$ and nuclear with $12.9 \%$. As for the same year, the share of fossil fuels in gross available energy in the EU was $72.5 \%$. When the types of fuel used to generate electricity in the EU are examined; it is seen that fossil fuels have a $44 \%$ share in total. This is followed by renewable energy with a rate of $30 \%$ and nuclear energy of $26 \%$. The rate of $30 \%$ for renewable energy includes the followings: hydroelectric power plants with $12 \%$, wind power plants with $9 \%$, bioenergy with $6 \%$, solar power plants with $3 \%$. As of 2018 , the installed renewable energy capacity in the EU has reached $282.7 \mathrm{GW}$, excluding hydroelectric power capacity. The wind power is leading, reaching the largest share of renewable energy capacity of the EU member states with $157.3 \mathrm{GW}$ with a share of $55.6 \%$. The total installed solar PV capacity reached $101.6 \mathrm{GW}$ by the end of 2018 in the EU, corresponding to $35.9 \%$. Bioenergy and waste have $10.8 \mathrm{GW}$ and $9.6 \mathrm{GW}$ of installed capacity, each corresponding to $3.8 \%$ and $3.4 \%$ share in the installed renewable power in the EU. Tide, wave and ocean and geothermal have miniscule amounts of power capacities. The EU's leading position in terms of the penetration of renewables within the total power 
capacity is expected to continue as the share of renewables in the EU power market is predicted to reach $50 \%$ by 2040.

The total installed power capacity of Turkey reached 88569 MW by the end of 2018. It has been presented that the installed capacity showed a geometric increase, doubling in every ten-year period between 1976 and 2018. The installed capacity of Turkey rose by a factor of 2.2 times from $40564 \mathrm{MW}$ to 88569 MW between the years 2006 and 2018. The fossil fuel power plants, namely natural gas, coal, biofuel and fuel oil, represent more than 50\% of the installed capacity in Turkey as of 2018. The share of fossil fuel power plants decreased gradually in recent years, from $56.6 \%$ in 2016 to $52.9 \%$ in 2018 . The largest share belongs to natural gas power plants within the fossil fuel power plants with 26568 MW, corresponding to $56.7 \%$ within this category. Fossil fuel based power plants are followed by the hydroelectric power plants, which represent almost one third of the installed power in Turkey. In 2018, electricity demand grew approximately $3 \%$ in Turkey in comparison to the previous year and reached $304200 \mathrm{GWh}$. It was noted that the electricity consumption per capita of 29 IEA member countries on average was $9900 \mathrm{kWh}$ in 2016 while that of Turkey was about $3500 \mathrm{kWh}$. It is evident that Turkey's electricity consumption per capita is too low when compared to the IEA average. It may be deduced that the electricity consumption per capita will increase relatively rapidly in Turkey in the years to come.

Regarding the renewable energy excluding hydro, wind energy leads, the cumulative wind capacity reaching $7005 \mathrm{MW}$ as of 2018 in Turkey. This is $8 \%$ of the total installed power of Turkey and only $14 \%$ of Turkey's technical wind power potential of $49 \mathrm{GW}$. The installed wind energy capacity grew almost 20 fold between the years 2008 and 2018, corresponding to an average annual growth of 37\%. The wind electricity generation was $19882 \mathrm{GWh}$ in 2018 , corresponding to $6.5 \%$ of the total electricity generation of the country. As of 2018, the installed PV capacity reached $5065 \mathrm{MW}$. The electricity generated through solar plants reached $7477 \mathrm{GWh}$ in 2018.

Turkey's high rate of economic growth leads to equally high rate of increase in the primary energy production and consumption [6]. This also equally translates into increase in Turkey's power generation capacity, mainly electricity. However, Turkey has only limited indigenous fossil fuel reserves, meaning that the amount of fossil fuel import has to increase to be able to satisfy the deficit of energy. As a result of this imbalance between the fossil fuel production and consumption, Turkey should turn to alternative energy sources, mainly to renewable energy sources, solar and wind energies being the main candidates.

\section{REFERENCES}

[1] V. Smil, Energy Transitions: History, Requirements, Prospects, $1^{\text {st }}$ Ed., Santa Barbara, CA, USA: Praeger, 2010.

[2] G. Chen, M. Hadjikakou, T. Wiedmann, and L. Shi, "Global warming impact of suburbanization: the case of Sydney," Journal of Cleaner Production, vol. 172, pp. 287-301, 2018.

[3] The British Petroleum. (2020, May 08). BP Energy Outlook 2019 edition [Online]. Available: https://www.bp.com/content/dam/bp/business-sites/en/global/corporate/pdfs/ energy-economics/energy-outlook/bp-energy-outlook-2019.pdf.

[4] International energy Agency (IEA). (2020, April 13). Key World Energy Statistics 2019 [Online]. Available: https://webstore.iea.org/key-world-energy-statistics-2019.

[5] The British Petroleum. (2020, May 08). BP Statistical Review of World Energy 2019 [Online]. Available: https://www.bp.com/content/dam/bp/businesssites/en/global/corporate/pdfs/energy-economics/statistical-review/bp-stats-review-2019-fullreport.pdf. 
[6] H. Saygin, H.V. Oral and S. Kardaslar, "Environmental assessment of renewable energy scenarios for a sustainable future in Turkey," Energy \& Environment; vol. 31 no.2, pp. 237$255,2020$.

[7] E. Maldonado and S. Yannas, "Passive and Low Energy Architecture," International Conference on Environmentally Friendly Cities: Proceedings of Plea, Lisbon, Portugal, 1998, pp. 41-48.

[8] The Organisation for Economic Co-operation and Development (OECD). (2020, April 14). Green Growth Studies: Energy [Online]. Available: https://www.oecd.org/greengrowth/greening-energy/49157219.pdf.

[9] International energy Agency (IEA). (2020, April 11). Data and Statistics 2020 [Online]. Available: https://www.iea.org/data-and-statistics?country=WORLD\&fuel=Energy $\% 20$ supply\&indicator=Total\%20 primary\%20energy\%20supply\%20(TPES)\%20by\%20source.

[10] The British Petroleum. (2020, May23). BP Annual Report and Form 20-F [Online]. Available: https://www.bp.com/content/dam/bp/business-sites/en/global/corporate/pdfs/investors/bpannual-report-and-form-20f-2019.pdf.

[11] International energy Agency (IEA). (2020, April 15). Data and Statistics, Installed power generation capacity [Online]. Available: https://www.iea.org/data-and-statistics/charts/installedpower-generation-capacity-by-source-in-the-stated-policies-scenario-2000-2040.

[12] P. Moriarty and D. Honnery, "Energy Accounting for a Renewable Energy Future," Energies, vol. 12, pp. 1-16, 2019.

[13] The International Renewable Energy Agency (IRENA). (2020, April 16). Future of Solar Photovoltaic: Deployment, investment, technology, grid integration and socio-economic aspects [Online]. Available: https://www.irena.org/media/Files/IRENA/Agency/Publication/2019/ Nov/IRENA_Future_of_Solar_PV_2019.pdf.

[14] J.R.F. Diógenes, J. Claro, J.C. Rodrigues and M.V. Loureiro, "Barriers to onshore wind energy implementation: A systematic review," Energy Research \& Social Science, vol. 60, pp. 1-33, 2020 .

[15] Wind Denmark. (2020, April 21). [Online]. Available: https://en.winddenmark.dk/wind-indenmark/current-energy-production.

[16] T. Trainer, "Some inconvenient theses," Energy Policy, vol. 64, pp. 168-174, 2014.

[17] Eurostat. (2020, April 18). Energy imports dependency [Online].

Available: https://appsso.eurostat.ec.europa.eu/nui/show.do?dataset=nrg_ind_id\&lang=en.

[18] Eurostat. (2020, April 18). Share of fossil fuels in gross available energy [Online]. Available: https://appsso.eurostat.ec.europa.eu/nui/show.do?dataset=nrg_ind_ffgae\&lang=en.

[19] Eurostat. (2020, April 18). Share of energy from renewable sources [Online]. Available: https://appsso.eurostat.ec.europa.eu/nui/show.do?dataset=nrg_ind_ren\&lang=en.

[20] Eurostat. (2020, April 18). Share of fuels in final energy consumption [Online]. Available: https://appsso.eurostat.ec.europa.eu/nui/show.do?dataset=nrg_ind_fecf\&lang=en. 
[21] Eurostat. (2020, April 18). Imports of oil and petroleum products by partner country [Online]. Available: https://appsso.eurostat.ec.europa.eu/nui/show.do?dataset=nrg_ti_oil\&lang=en.

[22] Eurostat. (2020, April 18). Imports of natural gas by partner country [Online]. Available: https://appsso.eurostat.ec.europa.eu/nui/show.do?dataset=nrg_ti_gas\&lang=en.

[23] Eurostat. (2020, April 18). Supply, transformation and consumption of solid fossil fuels [Online].

Available: https://appsso.eurostat.ec.europa.eu/nui/show.do?dataset=nrg cb sff\&lang=en.

[24] Eurostat. (2020, April 18). Supply, transformation and consumption of gas [Online]. Available: https://appsso.eurostat.ec.europa.eu/nui/show.do?dataset=nrg cb gas\&lang=en.

[25] Eurostat. (2020, April 06). Supply, transformation and consumption of oil and petroleum products [Online]. Available: https://appsso.eurostat.ec.europa.eu/nui/show.do?dataset= nrg_cb_oil\&lang=en.

[26] Eurostat. (2020, April 18). Supply, transformation and consumption of renewables and wastes [Online]. Available: https://appsso.eurostat.ec.europa.eu/nui/show.do?dataset= nrg_cb_rw\&lang=en.

[27] Eurostat. (2020, April 18). Electricity production capacities for renewables and wastes [Online].

Available: https://appsso.eurostat.ec.europa.eu/nui/show.do?dataset=nrg_inf_epcrw\&lang=en.

[28] S.Y. Saçık, N. Yokuş, M. Alagöz and T Yokuş, "Optimum Renewable Energy Investment Planning in Terms of Current Deficit: Turkey Model," Energies; vol. 13, pp. 1-21, 2020.

[29] G. Yılan, M.A.N. Kadirgan and G.A. Çiftçioğlu, "Analysis of electricity generation options for sustainable energy decision making: the case of Turkey," Renewable Energy; vol. 146, pp. 519$529,2020$.

[30] Turkish Electricity Transmission Corporation (TEİAŞ). (2020, May 7). Statistics: Turkey installed power by year [Online]. Available: https://www.teias.gov.tr/tr/i-kurulu-guc.

[31] Turkish Electricity Transmission Corporation (TEİAŞ). (2020, May 7). Statistics: Turkey installed power by source [Online].

Available: https://www.teias.gov.tr/sites/default/files/2018-03/kurulu_guc.pdf.

[32] Turkish Electricity Transmission Corporation (TEİAŞ). (2020, May 7). Statistics: Turkey electricity generation, consumption and loss [Online].

Available: https://www.teias.gov.tr/tr/iii-elektrik-enerjisi-uretimi-tuketimi-kayiplar.

[33] Energy Atlas of Turkey. (2020, May 7). Statistics [Online].

Available: https://www.enerjiatlasi.com/.

[34] Republic of Turkey Ministry of Energy and Natural Resources, General Directorate of Energy Affairs. (2020, May 8). Reports [Online]. Available: http://www.enerji.gov.tr/trTR/EIGM-Raporlari.

[35] Republic of Turkey Ministry of Energy and Natural Resources, General Directorate of Energy Affairs. (2020, May 8). Strategic Plan [Online]. Available: https://www.enerji.gov.tr/File/?path=ROOT\%2f1\%2fDocuments\%2fStrategic\%20Plan\%2fStr ategicPlan2015-2019.pdf. 
[36] N. Tamzok, "Coal in the world and in Turkey, Report: Energy outlook of Turkey 2018," Turkish Chamber of Mechanical Engineers, Chamber, Report No. 691, 2018.

[37] Republic of Turkey Ministry of Energy and Natural Resources. (2020, May 8). Info Bank Solar [Online]. Available: https://www.enerji.gov.tr/en-US/Pages/Solar.

[38] E. Özgür, "Solar Energy in Turkey, Energy Outlook of Turkey 2018," Turkish Chamber of Mechanical Engineers, Chamber Report No. 691, 2018.

Available: https://www.mmo.org.tr/sites/default/files/EnerjiGorunumu2018_1.pdf.

[39] Turkish Wind energy Association. (2020, May 8). [Online]. Available: http://www.tureb.com.tr/files/bilgi_bankasi/turkiye_res_durumu/istatistik_raporu_ocak_2019. pdf. 